\title{
Educational Preparedness of the Home Environment: A Technological Perspective Amidst Coronavirus (COVID-19) Outbreak
}

\author{
Edgar John Sintema ${ }^{1 *}\left(\mathbb{B}\right.$, , Derick Singogo ${ }^{2}$ (1)
}

${ }^{1}$ Universidad de Valladolid, SPAIN

${ }^{2}$ University of Zambia, ZAMBIA

*Corresponding Author: edgarsintema1@gmail.com

Citation: Sintema, E. J., \& Singogo, D. (2021). Educational Preparedness of the Home Environment: A Technological Perspective Amidst Coronavirus (COVID-19) Outbreak. International Journal of Pedagogical Development and Lifelong Learning, 2(1), ep2101. https://doi.org/10.30935/ijpdll/9290

\begin{abstract}
Schools in Zambia partner with students' families and communities through the Parents Teachers Association to promote community participation in the academic and social welfare of students. However, this partnership is sometimes weakened by unexpected external factors to the detriment of the students' educational development. This study used the theoretical lens of Epstein's School-Family-Community partnership model to examine the role of parents in the home environment in creating a supportive technological environment for school children in response to the effects of COVID-19 on education. To accomplish the purpose of the study, twenty parents responded to open-ended written interviews. Data were qualitatively analyzed using content analysis. Results revealed inadequate preparation of parents to respond to the academic needs of their school children. Households were facing numerous challenges in procuring curriculum materials like prescribed textbooks. Further, it was revealed that electricity load shading negatively affected students' access to the educational content on television and e-learning facilities aimed at supplementing school classroom instruction. The study concluded that there were limited or no technology resources in Zambian homes to support students' access to education during the COVID19 period.
\end{abstract}

Keywords: educational preparedness, home environment, partnership, COVID-19

Received: 17 Aug. 2020 Accepted: 3 Oct. 2020

\section{INTRODUCTION}

In Zambia, schools partner with students' families and communities through the parents-teachers-association (PTA) meetings to promote community participation in the academic and social welfare of students. However, this partnership is sometimes weakened by unexpected external factors to the detriment of students' educational development. It is crucial to understand how the two institutions complement each other's efforts in making sure that the child receives maximum educational benefits. The current study is crucial to both the school and home environments in planning interventions that would ensure that there were no gaps in the education of children. To the local context the study would help education providers like schools to plan how to ensure that school children continued to learn even away from school by providing educational support while students were at home. To the international context this study will contribute lessons on educational challenges that students in developing countries face when accessing basic curriculum materials to keep them in sound academic state when schools close. The study can also be replicated in international contexts to bring out international perspectives on the topic being investigated.
Home Environment vs School Environment

The home environment's importance in the intrinsic academic motivation of a child is at par with that of the school. Both have a key role to play in the academic development of the child especially that they complement each other in ensuring that the child is academically highly motivated at all times. A child whose home environment is academically demotivating can rarely boast of high academic achievement at school and a child whose school environment is demotivating is likely to exhibit low confidence at home. Previous research has showed evidence of studies, which like the present study, focused on the home environment as an academic cognitive stimulating agent to the child (Gottfried et al., 1998; Zippert \& Rittle-Johnson, 2018).

With effects of the outbreak of coronavirus (COVID-19) which have prompted the closure of all public and private schools in Zambia (Sintema, 2020), the home environment has emerged as the only place where the child would continue with his/her educational development. This is also due to the presidential directive in Zambia that all citizens practice self-isolation and social distancing in order to curb the spread of the COVID-19 pandemic. Thus, for the average Zambian home to be

( 2021 by the authors; licensee IJPDLL by Bastas, UK. This article is an open access article distributed under the terms and conditions of the Creative Commons Attribution License (http://creativecommons.org/licenses/by/4.0/). 
considered educationally prepared to support a school going child with educational development and be academically motivating, basic educational resources like textbooks, internet access and studying space need to be available.

In a home setup a parent is an essential supporting resource to the educational needs of a child (Chansa-Kabali, 2014; Napoli \& Purpura, 2018; Zippert \& Rittle-Johnson, 2018) in reading, numeracy and many other areas. Parents also offer support to the school going children by providing a conducive home environment for their children to engage in academic work. However, there have been reports of a weak relationship between the home and the school in Zambia (ChansaKabali, 2014). This has the potential to negatively affect a child's educational achievement at school. Frequent interaction between the school and the parents through parents-teachers-association (PTA) meetings can help strengthen the relationships because PTA meetings offer a good opportunity for parents and teachers to interact.

Opportunities and Challenges Regarding Access to Educational Technology in the Home Environment

The unexpected outbreak and rapid spread of the coronavirus pandemic meant that students at all levels of education in many countries had to be forced to stay home. In fact, in Zambia the "stay home" campaign is on all media platforms. Sensitization campaigns about the COVID-19 pandemic are slowing down on using the "selfisolation" phrase in favour of the friendly "stay home" which seems to be easily understood by every citizen.

So far, educational research related to COVID-19 has focused exclusively on the school environment (Basilaia, 2020; Basilaia, Dgebuadze, Kantaria, \& Chokhonelidze, 2020; Cakir \& Savas, 2020; Germann et al., 2019; Mulenga \& Marban, 2020; Qi, 2017; Sintema 2020; Toquero, 2020) with emphasis on different aspects of the school environment that could be affected. For many developing countries whose educational sectors are suffering from inadequate teaching and learning materials, lack of e-learning facilities due to inadequate funding, effects of COVID-19 have so far had a negative impact on the learners while in developed countries with readily available resources the pandemic has presented opportunities for transitioning to using elearning platforms in schools and higher learning institutions (Toquero, 2020). In other contexts the effects of this pandemic is being viewed to have a negative impact on the performance of students in forthcoming national examinations (Sintema, 2020).

Regarding higher education, universities across the world have been making use of their virtual and online teaching facilities to keep students up to date with academic work (Basilaia, 2020) and Zambia has been up to speed on this initiative (Mulenga \& Marban, 2020). In the latest development, Ministry of Education in Zambia launched an educational television channel on 13 April 2020 dedicated to teaching in all subjects taught in secondary schools. This was aimed at giving students access to education during the COVID-19 period but it will continue to exist even after the pandemic has ended. However, this gesture comes amid several challenges for a country which has a deficit in electricity.

On average, every household in Zambia does not receive electricity supply for at least eight hours daily and in many cases this coincides with the lessons being aired on national television. This means that during this period students lose out on the lessons being televised. The situation is even worse in rural areas where most students have no access to a television set. The Ministry of Education is preparing modules for students in rural areas to help them with materials to read. Thus, while in urban settings the availability of digital television has created opportunities for an innovative approach to teaching, in rural Zambia COVID-19 has presented challenges for students to access education because the technology in urban areas is not available in rural areas (Toquero, 2020).

Many homes in Zambia lack technology tools like computers, laptops and overhead projectors that can be used to support learning. Internet access is also limited. Many citizens access internet via mobile phones which are not adequate for educational purposes. This lack of technology tools makes the home environment to limit students' opportunities to access education through e-learning platforms.

Threats to Educational Access Posed by Coronavirus (COVID-19) Outbreak

The emergency of COVID-19 has posed numerous threats to the education sector in Zambia and other parts of Africa and the world. Some of the immediate threats to education include access to education by school going children and educational funding. For developing countries like Zambia which partly depends on external funding to sustain various sectors which include education, we risk receiving reduced funds because economies of the potential funders have also been affected by the effects of COVID-19 (Sintema, 2020). Some school going children are sponsored by Non-Governmental Organisations (NGOs) which are externally funded. Reduced funding to such organisations would mean reduction in the number of sponsored children who are mostly single or double orphans. The future of education for such children is highly threatened if the COVID-19 pandemic is not arrested in the shortest possible time.

With regards to children's access to education, the problem is already being experienced. For the period of COVID-19 most school children in Zambia will have little or no access to education vis-à-vis contact with teachers. Majority of schools in Zambia have no e-learning facilities that students can use at home to access online lessons or electronic learning materials. This means that students are completely cut off from accessing school learning materials like books and accessing their teachers for any form of academic assistance (Sintema, 2020). The biggest threat COVID-19 poses to children's access to education is to students in rural areas and those in urban areas who have no access to national television to follow lessons being televised on the newly launched educational channel.

Considering that some students come from families that depend on small scale businesses, issues of school fees are likely to emerge as limiting factors for these children to go back to school. Families are unable to conduct their businesses normally due to COVID-19 and their financial base is being depleted every day. This is being seen as a potential threat to their capacity to pay school fees for their children. Thus, the home environment and the school environment will suffer from financial problems in a bid to offer quality education to the child. The school is expected to have reduced income from tuition fees resulting from parents' failure to fully commit themselves to their financial obligations. This could affet the smooth running of many schools.

\section{Theoretical Perspective}

The study was anchored on Epstein's school-family-community theoretical model (Figure 1). The model emphasizes the role of school, family and community in children's education. If all parties are aware of 


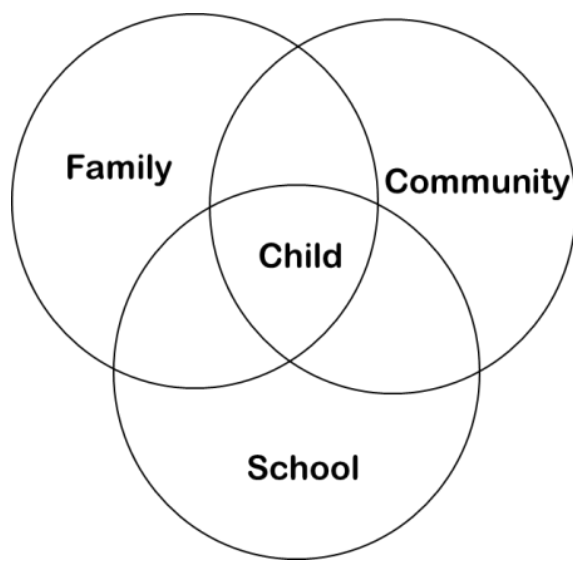

Figure 1. School-family-community theoretical model

their own responsibilities while recognizing other's roles, they would meaningfully contribute to the education of the child. Parental involvement as guided by the aforesaid model involves effective communication between school and home, promoting parenting skills in order to enhance child rearing skills. Volunteering in school activities and participation in decision making as well as coordinating resources through collaboration with the community are significant components in the child's education. Further, learning at home provides a link between learning activities at school and those taking place at home (Epstein, 1995). In Zambia, the outbreak of COVID-19 pandemic has influenced a weak link between the school and parents due to the "stay home" campaign and sensitization on self-isolation in order to prevent the spread of the disease. The home environment emerges as a critical entity in the continued education of the child during this period. The model under review, therefore, is significant in the current study to explore the educational preparedness of the home environment amidst COVID-19 with a particular attention to the use of technology in educational acquisition.

\section{METHODOLOGY}

\section{Subjects}

The study purposefully recruited 20 male and female parents who voluntarily consented to participate. Participants were told that they reserved the right to withdraw from the study at any point if they felt the need to do so. All the participants were parents to at least one biological child who was a student at some school. The criteria for selection of participants was that one needed to be a biological father/mother to at least one child who attended either primary, junior secondary or senior secondary school. Participation was not restricted to indigenous Zambian parents. This is because there are a lot of Zambians originating from other countries, for example, Zambians of Indian origin. The idea was to ensure that the study was inclusive and non-discriminatory.

\section{Instruments}

The study used a validated questionnaire to collect data from 20 parents originating from a community in Chipata District. The interview protocol comprised 24 interview questions spread across 3 domains. Eight questions were addressing issues relating to parents' views about the home environment versus school environment; eleven questions addressed issues relating to parents' views about children's access and use of technology in the home environment. Five questions were about parents' knowledge about coronavirus (COVID-19) disease.

\section{Data Gathering}

Due to the presidential directive for all citizens to self-isolate and practice social distancing (Sintema, 2020), the interview protocol was printed with enough space for interviewees to write their responses in detail. They were also encouraged to answer questions by giving examples and clarifications where necessary. The data collection period was two weeks from 25 March to 7 April 2020. This was aimed at giving parents enough time to adequately respond to the interview questions considering that all of them were full-time employs in different work places and they were to accommodate the interview in their busy schedules.

\section{Data Analysis}

To analyze data obtained from the questionnaire, we used Sabar Ben-Yehosua's (1995) protocol for analyzing qualitative data as implemented by Dor (2012). In the initial stage of this content analysis technique, we engaged in a systematic search for repetitive and visible words/phrases and phrases from participants' written interview texts. Then we analyzed the frequency of appearance of these words and phrases according to how we interpreted them to be important in the interviewee's perspective. We then derived prominent themes from the data during our interpretations and assigned them some labels.

\section{FINDINGS}

To meaningfully present the results three aspects were addressed which provided a detailed account pertaining to the home environment. The results are presented by highlighting (i) parental educational support to their children at home, (ii) children's access and use of technology in the home environment and (iii) parents' Knowledge about coronavirus (COVID-19) disease. Presenting results using these three domains resulted in an in-depth understanding of how prepared the home environment is for the educational development of school children during the COVID-19 period. The participants were identified using pseudonyms. The names contained in this paper are not the real names of the participants.

\section{Parental Educational Support}

To find out parental involvement in their children's education we collected data related to the educational support children received from their parents. It can be seen in Table 1 that 4 parents had children who attended early childhood education, 13 had their children attending primary school, 8 had children at Junior secondary school, 14 had children who attended senior secondary school and 3 had children in either college or university. Thus, in terms of school attended, the sample was representative with parents having children who attended at least one of the grade levels from early childhood to university.

It can further be seen from Table 1 that all the parents managed to buy school essential requirements for their children. It was not surprising because every child at school is expected to have pens, pencils, exercise books and school uniform. Schools in Zambia actually demand to see these items before a child can be admitted to class. However, only 16 out of 20 parents bought textbooks for their children. Those that failed to buy text books cited lack of money as the major reason for their failure to provide these learning materials. Considering 
Table 1. Educational material support of parents

\begin{tabular}{|c|c|c|c|}
\hline \multirow{2}{*}{ Question } & \multirow{2}{*}{ Theme } & \multicolumn{2}{|c|}{ Frequency $(\mathrm{N}=20)$} \\
\hline & & Yes & No \\
\hline \multirow{5}{*}{ School going children } & Early childhood & 4 & 16 \\
\hline & Primary & 13 & 7 \\
\hline & Junior secondary & 8 & 12 \\
\hline & Senior secondary & 14 & 6 \\
\hline & Tertiary & 3 & 17 \\
\hline Provision of school materials & Provided & 17 & 3 \\
\hline \multirow{2}{*}{ List of specific materials } & Text books & 16 & 4 \\
\hline & Other essentials (pens, pencils, uniforms, exercise books) & 20 & 0 \\
\hline Home environment support self-study & Support & 10 & 10 \\
\hline
\end{tabular}

Table 2. Parental involvement in children's educational affairs

\begin{tabular}{|c|c|c|}
\hline Question & Theme & Frequency $(\mathrm{N}=20)$ \\
\hline \multirow{3}{*}{ What is your role in your child's education? } & Payment of school fees & 6 \\
\hline & Monitor and encourage the child to study hard & 15 \\
\hline & Provide educational materials for the child & 5 \\
\hline \multirow{2}{*}{$\begin{array}{l}\text { How is your relationship with the school authorities where your child } \\
\qquad \text { learns? }\end{array}$} & Good and cordial & 18 \\
\hline & Distant with no communication & 2 \\
\hline \multirow{4}{*}{ Do you attend PTA meetings? Why? } & Yes I do & 18 \\
\hline & To discuss the progress of the children & 8 \\
\hline & To know the school fees being paid & 3 \\
\hline & To know the challenges the school faces & 9 \\
\hline
\end{tabular}

the suitability of the home environment for school children to engage in self-study, the number of parents who said that their home provided a conducive environment for the children to engage in self-study was equal to those who said otherwise. Of the 10 parents who said that the home environment was suitable for self-study, one parent, Morgan, said

We have set up a library within the house; children do not need to go elsewhere to study. There is a quiet environment which is children's own room. We let them work on their studies everyday at scheduled times of the day. They have a lot of time since they are confined, with little movements out of home

On the contrary, one of the 10 parents, Susan, whose home environment was not conducive for children's self-study said

There are lots of disturbances since everyone [members of the household] is at home. $\mathrm{i}$ [also] have provision for studies in my home. There is not enough space and there is no electricity.

In view of the responses obtained from parents regarding educational support they rendered their children, all the parents were able to provide essential materials needed for their children to attend school. This meant that children were receiving adequate material support necessary for them to fit into the school environment well. Majority of the parents (16 out of 20) were also able to buy textbooks for their children which they can use at home for studying. With personal textbooks, children are able to engage in successful self-study because textbooks are important reference materials. The foregoing results were related to questions that sought to find out the level of education of children whose parents participated in the study, whether or not parents bought textbooks and other essential materials for their children, and the suitability of the home environment for children's self-study.
To further understand parental education support of parents, they were asked questions related to their relationship with school authorities where their children were enrolled, whether they attended Parents-Teachers-Association (PTA) meetings and their self reported roles in the children's education. Their responses saw the emergence of themes that detailed parental involvement in children's educational affairs (Table 2).

\section{Question: What is your Role in your Child's Education?}

As depicted in Table 2, all the parents claimed that they had a role to play in the education of their children. They stated their responsibilities that defined their involvement in the educational affairs of the children. Three themes emerged from their explanations namely: (i) Payment of school fees, (ii) Monitoring and encouraging the child to study hard, and (iii) Providing educational materials for the child.

\section{Theme 1: Payment of school fees (6 out of 20 parents)}

Some of the parents defined their role by claiming that their major responsibility was to pay the child's school tuition fees and fees related to private after school coaching of the child. The six parents who defined their role as payment of school tuition fees were predominantly male. One of the parents, Chomba, said:

Actually, I am not very responsible. My responsibility is to see to it that i pay all school fees and to pay for all school requirements for my children. I also find money for their private tuitions. My wife is the one who tells me that the [private] teacher had come and he has done his work.

Theme 2: Monitoring and encouraging the child to study hard (15 out of 20 parents)

Most of the parents claimed that their role in the child's education included monitoring the child's academic performance, out of school movements and the company that the child kept. They also claimed that 
they had a responsibility to encourage the child to study hard and attend all lessons at school. A parent, Siankondo, stated that:

I make sure that my children behave well, do better in school, engage themselves more with school work, go to school regularly and have better social skills. Monitoring their daily performance in school and making sure they perform well in their homework and other school activities.

Another parent, Mweemba, said:

I encourage children to study hard by making sure that the child has time for books at home or studying every day and making sure they eat well before going to school so that they concentrate much on studies.

However, a parent, Malambo, said that he would rather keep the children home all the time. He stated that:

As a parent, I make sure they don't move out of the house with or without electricity since they are good in watching television and i normally advise them not to play with their friends though i feel very bad because friends are also complaining for lack of interaction.

\section{Theme 3: Providing educational materials for the child (5 out of 20 parents)}

Some parents defined their key role in the education of their children as provision of school related materials. They claimed that it was their responsibility to provide school uniform, shoes, exercise books, mathematical set, school bag Et cetera. in this regard, a parent, Situmbeko, said:

I provide educational materials such as books, pen, pencil, rubber, ruler and mathematical set. i also assist in their studies where necessary. I also provide other things like good food and shelter, and help supplement all the required extra lessons for the child.

Question: How is your Relationship with the School Authorities where your Child Learns?

Analyzing Table 2, we see that majority of parents claimed that their relationship with the school attended by their children was good and cordial. Such a relationship is good for the child because the school and child's parents are able to keep good communication. Two themes emerged from responses to this question: (i) good and cordial (ii) Distant with no communication.

\section{Theme 1: Good and cordial relationship (18 out of 20 parents)}

Most of the parents claimed that they enjoyed a good and warm relationship with the school. There was constant flow of communication from both ends regarding the children's welfare and how the home and the school could complement each other in building a responsible citizen out of the child. One of the parents, Likezo, said:

There is good relationship. We are always in touch with the school staff and we communicate whenever necessary. For the relationship I can say that so far so good although we are forced to pay extra fees apart from the agreed ones.

\section{Theme 2: Distant with no communication (2 out of 20 parents)}

Notwithstanding the good relationship most of the parents enjoyed with the school, some parents claimed that their relationship with the school authorities was low, distant and lacked communication. Of those parents, Zulu, explained that:

The relationship is low and too distant. I should say that there is no communication with the school

\section{Question: Do you Attend PTA Meetings? Why?}

Majority of parents (18 out of 20 parents) claimed that they attend PTA meetings at the schools where their children learn (Table 2). They gave various reasons for attending such meetings. The reasons included monitoring how the school was using funds and whether it was implementing proposed projects, and to have personal discussions with subject teachers for their children relating to the academic progress of the children. Three major themes emerged from parents' responses: (i) To discuss the progress of the children (ii) To know the school fees being paid (iii) To know the challenges the school faces.

\section{Theme 1: To discuss the progress of the children (8 out of 20 parents)}

Some parents who attend PTA meetings claimed that they did so to discuss academic progress of their children with teachers. This could be because teachers keep track of the academic record of every child under their tutelage and PTA meetings which happen once a year serve as a rare opportunity for parents to interact with subject teachers. One of the parents, Banda, gave the following reasons for attending the meetings:

I attend PTA meetings so as to be enlightened about the academic progress of the children and to find ways of improving the school environment. The other reason is to discuss the welfare of the children at the institution. This is because it is important to know how well they [school] are taking care of their pupils. It is also good to hear what the school has to say about the children and to find out what has been happening.

\section{Theme 2: To know about the school fees being paid (2 out of 20 parents)}

Few parents said that they attend PTA meetings mainly to find out how the school collects school fees and whether parents were supporting the school by meeting their obligation of paying school fees on time because school fees would help the school to run smoothly. A parent, Mbuzi, explained that:

I attend PTA meetings because i should know the requirements of the school regarding tuition fees. I also attend because they help parents to know how the school fees being paid by their children are spent by the school. During the meeting we agree with the school about activities to involve our children in, projects to be undertaken, tuition fees to be paid and to know what else is needed by the school.

As for the parents who do not attend PTA meetings, one said her child was enrolled at a private school where there was no ParentsTeachers-Association (PTA). Another said that he was he was normally busy with work while the other one said that he did not attend because the school where his child attends was very far. It was, however, surprising that a parent would enroll his child in a school that is too far 
Table 3. Availability of internet, connecting gadgets and children's access to internet in the home environment

\begin{tabular}{|c|c|c|}
\hline Question & Theme & Frequency $(\mathrm{N}=20)$ \\
\hline \multirow{5}{*}{ Are these gadgets available in your home? } & Smart phone & 17 \\
\hline & Desk computer & 2 \\
\hline & Tablet & 4 \\
\hline & Laptop & 8 \\
\hline & Television set & 15 \\
\hline Do you have internet service at home? & Yes & 11 \\
\hline \multirow{5}{*}{ Which gadgets does your child use to access internet? } & Smart phone & 11 \\
\hline & Desk computer & 0 \\
\hline & Tablet & 1 \\
\hline & Laptop & 2 \\
\hline & Television set & 6 \\
\hline
\end{tabular}

for him to attend PTA meetings aimed at discussing the welfare of his child. Secondly, it was expected that a parent would not be too busy with work commitments to attend PTA meetings because such meetings were usually held on Saturdays.

\section{Theme 3: To know the challenges the school was facing (9 out of 20 parents)}

Some parents claimed that they attended PTA meetings to learn about the challenges that the school was facing and generally what was happening at the school. One parent, Mwale, who gave a comprehensive explanation said:

I have been a PTA member at Kanjala secondary school and i always attend the meetings to be informed about how the school operates, to know what comes out and any issues teachers come across. I want to be kept up to date with school projects, development and the school progress in academics. PTA meetings help me to know the challenges the school faces in providing education and some adjustments that are needed to fully support the school management. The other reason is that i want to be part of the affairs of the school, to advise them [school authorities] or correct them where necessary and to know what the school requires.

\section{Access and use of technology in the home environment}

With the closure of all learning institutions and introduction of elearning platforms by the Ministry of General Education, it was important to gain insight about how learners were accessing these services, if they were, and the availability of e-learning tools that would support the accessibility of e-learning. It was also crucial to assess the suitability of the home environment for e-learning. The following responses from parents summarized children's access and use of technology in the home environment.

The first four questions were aimed at finding out about the availability of internet in the home environment, tools or gadgets that are used to connect to the internet and whether children ahave access to internet in the home environment. Responses to these questions provided in-depth information about how the children where accessing e-learning platform introduced by the Zambian government in the third week of April 2020.

According to the statistics in Table 3, majority of the households owned smart phones (17 out of 20 parents) and Television sets (15 out of 20 parents). Less than half of the households owned either a laptop ( 8 out of 20 parents), Tablet ( 4 out of 20 parents) or Desktop computer
( 2 out of 20 parents. It was further revealed that 11 households had internet service at their homes and children in these (11 out of 20) households were able to access internet. Table 3 also shows that in 11 out of 20 households, children accessed internet via smart phones while no child used a desktop computer to access internet at home. It can also be seen that children in 6 out of 20 households accessed internet via Television, 2 out of 20 via laptop while on one household accessed internet via a laptop.

The other four questions invited parents to explain used the gadgets to access internet and how parents ensured that the internet was being used for educational purposes. Parents were also asked to state if they were aware of the newly opened educational channel and to explain how load shading was interfered with the educational TV programming. They were also asked to explain the extent to which their children were benefitting from the educational TV channel during the COVID-19 quarantine period when all schools were not operational.

Question: Explain how your Child Uses the Internet and the Gadgets Present at Home for Educational Purposes

Majority of parents claimed that their children used home internet for educational purposes. The use included downloading educational materials like books and searching for new information. Other said that their children were limited to watching educational content on TV. Responses to this question resulted in two themes: (i) Watching educational content on TV and (ii) Using Google to download educational material.

\section{Theme 1: Watching educational content on TV (7 out of 20 parents)}

Less than half of the parents stated that their children were limited to watching educational programmes on national television because they did not own either laptops, tablets or desk computers. One parent, Mwanza, explained that:

My children do not use any technology apart from TV. We let them watch educative programmes to improve their knowledge and skills. They watch shows like health talk. The child doing early childhood watches educational cartoons like Akili which comes on Zambia National Broadcasting Corporation (ZNBC)TV. They also watch educational programmes on DSTV channel 314 and 319.

Theme 2: Using Google to download educational material (16 out of 20 parents)

Majority of parents whose children had access to internet claimed that their children used smart phones, tablets or laptop to view and 
Table 4. Children's use of internet and access to the educational Television channel

\begin{tabular}{|c|c|c|}
\hline Question & Theme & Frequency $(\mathrm{N}=20)$ \\
\hline \multirow{2}{*}{$\begin{array}{l}\text { Explain how your child uses the internet and the gadgets present at home } \\
\text { for educational purposes }\end{array}$} & Watching educational content on TV & 7 \\
\hline & Using Google to download educational material & 16 \\
\hline $\begin{array}{l}\text { Are you aware that government has opened an educational TV channel } \\
\text { and will soon be launching an e-learning and smart revision portal? }\end{array}$ & Yes I am aware & 13 \\
\hline \multirow{2}{*}{ Explain how you think the channel helps your child } & It does not help & 8 \\
\hline & It helps children to study and learn & 12 \\
\hline
\end{tabular}

download educational materials. Mercy, a parent to one of the children said:

My child uses mobile phone which has access to internet to browse files containing learning materials like books, [examinations] past papers and pamphlets and sites where lessons are done. When she has difficult in understanding some words they refer to Google for help. Also, when she needs more information she watches educational tutorials and articles. She also uses it for computer studies practical lessons.

Question: Explain how you Think the Channel Helps your Child

According to Table 4, majority of parents were aware of the introduction of the education channel on national television by the Ministry of General Education and intentions to launch the e-learning and smart revision virtual classroom. Parents' views about how they thought the channel helpful to their children were sought. Two themes emerged: (i) It helps children to study and learn, and (ii) It does not help.

Theme 1: It helps children to study and learn (12 out of 20 parents)

Most parents claimed that the educational channel helps their children to learn and revise during the period that they were away from school due to COVID-19 outbreak. One parent, Mwaka, said:

It has really helped them because they have less time to play. The children are kept up to date with the syllabus, they always study and learn on this educational channel and they also get reminded of previous topics covered in grade 8 .

Another parent, Mumba, explained that:

The lessons indicated on the schedule seem to be compacted and help the children. The channel helps the children not to forget about school. It helps them not to become lazy in the community and avoid unnecessary movements. i think they also learn where covid-19 originated from, how it is spread, symptoms, signs and its prevention. they even follow the covid19 status and updates.

\section{Theme 2: It does not help (8 out of 20 parents)}

Some parents claimed that the Television programme was not helpful to their children. One of the parents, Concilia, said:

The programme is good but none of my children are benefiting because it is focused on secondary school pupils not primary or early childhood learners.
The channel which they introduced does not help in any way because (1) we have to pay for DSTV connectivity (2) we have a problem with power because it normally goes during the day and comes back at night when a child is learning on TV. Besides, how is he going to ask a question through the TV on issues he doesn't understand?

Question: Explain how Load Shading Interferes with your Child's Access to this Educational Channel

With Zambia facing challenges of electricity deficit which has caused hours of load shading, we sought parents' views about how this problem affects children's access to the educational TV programme. Most of the parents expressed displeasure about the long hours they stayed without electricity and lamented how it interferes with access to the educational TV programme. One theme emerged from parents views: Load shading takes too long and interferes with the time of the broadcast.

\section{Theme 1: Load shading takes too long and interferes with the time of the broadcast}

Load shading was noted by most of the parents as a hindrance to children's access to educational programming on national television. The views of the parents were that:

Well, load shading is a very big problem we have in our country and it affects our children negatively. This is because most of the times we have power at night and during the day we have no power when it is appropriate time for the child to learn. The time power goes is the time scheduled for them to study. They cannot study with lights are off. Load shading has become a great barrier to children access to this education channel. So, due to unpredictable load shading schedule, children rarely watch TV. Vital subjects like mathematics do not need disconnected coverage. they need step by step learning for children to grasp properly. Even personal study is not achieved with the use of hard copies due to load shading especially at night. The government should look into it.

\section{Parents' Knowledge about coronavirus (COVID-19) disease}

With the closure of schools, all children are at home. This being the case, it is incumbent upon parents to ensure that their children are fully protected from contracting COVID-19. To achieve this parents are expected to exhibit basic knowledge about COVID-19, how it is spread and preventive practices that can be introduced in the home environment and the community. Table 5 highlights parents' knowledge about the COVID-19 pandemic.

Another parent said: 
Table 5. Parents' knowledge of the coronavirus (COVID-19) disease

\begin{tabular}{cc}
\hline Q uestion & Theme \\
\hline Explain what you know about COVID-19 disease & It is a respiratory disease \\
\cline { 2 - 2 } $\begin{array}{c}\text { Explain measures that you have devised for your household to avoid } \\
\text { contracting the disease }\end{array}$ & $\begin{array}{c}\text { It is transmitted from human to human through cough and sneeze } \\
\text { droplets from an infected person to another }\end{array}$ \\
\cline { 2 - 2 } $\begin{array}{c}\text { How are you and your community adhering to the intervention } \\
\text { measures that the ministry of health has outlined for the country }\end{array}$ & $\begin{array}{c}\text { Wearing face masks when going out of the house and avoid contact } \\
\text { with people }\end{array}$ \\
\hline
\end{tabular}

Most of the parents exhibited basic knowledge about COVID-19 which can help their families and community to avoid contracting the disease. It was clear from their submissions that most of them were practicing social distancing and washing hands regularly with soap.

\section{Question: Explain what you Know about COVID-19 Disease}

Majority of parents had good knowledge of COVID-19. They were able to state that is a respiratory disease caused by a virus which at the moment had no cure. They were also able to explain that the pandemic mainly spreads from human to human through contact with an infected person and can be prevented by regular washing of hands, disinfecting walls and avoiding crowded places. Two themes emerged from their responses: (i) It is a respiratory disease (ii) It is transmitted from human to human through cough and sneeze droplets from an infected person to another.

\section{Theme 1: It is a respiratory disease (14 out 20 parents)}

Parents explained that CVID-19 is a respiratory disease that is cause by a virus and spreads from human to human through contact. A parent, Lungu, said:

Covid-19 is a respiratory disease that is caused by a virus and said to have originated from animals and then pass on to humans. It is manifested in various ways such as short breath, sneezing, cough, high temperature, body pains. It originated from Wuhan, China and has spread all over the world. There is no cure and no vaccine at the moment.

Theme 2: It is transmitted from human to human through cough and sneeze droplets from an infected person to another (17 out of 20 parents)

Majority of the parents were able to clearly explain how COVID19 is contracted, how it is spread and ways of preventing it. A parent, Zimba, explained that:

Covid-19 is deadly virus which is transmitted from human to human. It enters the body mostly through membranes in the eyes, mouth and nose. Even by close contact with a person [who is infected] with a virus. It is spread by a virus through the air. One can contract it through handshake and if you have contact with an infected person. It can be prevented by wearing a face mask and washing hands frequently with soap or alcohol based sanitizers and staying home (quarantine).

Question: Explain Measures that you have Devised for your Household to Avoid Contracting the Disease

To conquer COVID-19, it was the responsibility of every parent to outline measures for the household that would help prevent all members from contracting it. Two themes noted from their explanations: (i) Wash hands regularly with soap and disinfect surfaces of the house and (ii) Wearing face masks when going out of the house and avoid contact with people.

Theme 1: Wash hands regularly with soap and disinfect surfaces of the house (20 out of 20 parents)

All the parents emphasized the need to wash hands regularly with medicated soap and to keep the home surrounding clean and to make sure that all the surfaces are disinfected. They said:

A bucket of water is placed at the passage with liquid soap. Everyone washes hands first thing when they come home. Also, by making sure that body contact is avoided at all times and avoiding touching eyes .nose and mouth. Washing the hands regularly with medicated soap or hand sanitizers is a rule we have put up. No shaking hands when greeting friends. We avoid staying in groups. There is no coughing carelessly in public and no sneezing. Everyone is encouraged to hold the mouth when sneezing. We have disinfected surfaces of the house.

Theme 2: Wearing face masks when going out of the house and avoid contact with people (20 out of 20 parents)

Regarding masks the parents said:

Everybody is told to wear a face mask covering the nose and mouth when going out of the house. We have agreed on reducing visits to the neighbours. We have agreed to stay at home as the first priority then social distancing outside the house.

Question: How are you and your Community Adhering to the Intervention Measures that the Ministry of Health has Outlined for the Coun try?

The Ministry of Health outlined measures that all citizens needed to follow. The measures were to be implemented at individual, household and community levels. Most of the parents said their households and community were adhering to these guidelines.

Theme 1: Social distancing and avoid crowded places (18 out of 20 parents)

Regarding social distancing, one parent said:

At least some people are taking it seriously and some are not treating it with the seriousness it deserves. some people are keeping the one meter distance apart and are avoiding crowded places. Those with shops are placing buckets and making sure people wash their hands to avoid getting the disease.

Another parent said: 
According to my observation, $\mathrm{i}$ feel there is negligence when it comes to the community, [people are] almost taking it for granted. The response is casual generally. There is resistance from some individuals to comply. Not everyone washes hands. I found out that though some people are adhering to the prevention measures set, others just live careless as if there is no deadly disease, walking about aimlessly with no masks. However, not all people are able to stay home due to economic hardship. Some go to work or sale so as to earn some money to buy basic needs.

\section{DISCUSSION AND CONCLUSION}

The purpose of this study was to examine the educational preparedness of the home environment regarding the use of available technology to continue the education of the children amidst COVID19. Results of the study have revealed that there is inadequate provision of learning materials in the home environment like textbooks and other documents that children can read while at home. It has also been shown that while some households have internet supply and own gadgets that can connect to the internet, other households lacked such facilities. This implies that even with the availability of learning materials online some children cannot access them.

Regarding the educational channel on national television, most parents submitted that their children were not able to fully benefit from the lessons being aired due to electricity power outages which where usually unpredictable. In some cases households would stay for several hours without electricity making children miss educational content on TV. With regards to parental knowledge of COVId-19 disease, most parents showed that they possessed good knowledge fo the pandemic and were able to take preventive measures as individual households and collectively as a community.

In conclusion, the home environment is not fully prepared to help children develop their education away from school though results indicate that steps are being taken to increase opportunities for children to engage in studies at home. Parents still need to do more to supplement the efforts of the school in this period when COVID-19 has prevented teacher-pupil contact. The involvement of parents in the education of their children can make a very huge difference in the education achievement of the pupils.

\section{Implication for Further Studies}

This study is a springboard for a very educative discussion about the way parents in the home environment are responding to the effects of COVID-19 on their children's education and how the emergence of the pandemic presents opportunities for the use of technology within the home environment for educational purposes. This study is by no means exhaustive about the educational preparedness of the home environment to use technology for education. Further insight can be gained by use of oral interviews to probe more widely around the same topic. Other studies can consider a larger sample whose findings can be generalized to a wider context. This study can also be replicated in other parts of Zambia to (i) validate the current study and (ii) learn about views of parents from different settings.

\section{REFERENCES}

Basilaia, G., \& Kvavadze, D. (2020). Transition to Online Education in Schools during a SARS-CoV-2 Coronavirus (COVID-19) Pandemic in Georgia. Pedagogical Research, 5(4), em0060. https://doi.org/10.29333/pr/7937

Basilaia, G., Dgebuadze, M., Kantaria, M., \& Chokhonelidze, G. (2020). Replacing the Classic Learning Form at Universities as an Immediate Response to the COVID-19 Virus Infection in Georgia. International Journal for Research in Applied Science \& Engineering Technology (IJRASET), 8, 101-108. https://doi.org/10.22214/ ijraset.2020.3021

Cakir, Z., \& Savas, H. B. (2020). A Mathematical Modelling Approach in the Spread of the Novel 2019 Coronavirus SARS-CoV-2 (COVID-19) Pandemic. Electronic Journal of General Medicine, 17(4), em205. https://doi.org/10.29333/ejgm/7861

Chansa-Kabali, T., \& Westerholm, J. (2014). The role of family on pathways to acquiring early reading skills in Lusaka's low-income communities. Human Technology: An Interdisciplinary Journal on Humans in ICT Environments, 10(1), 5-21. https://doi.org/ 10.17011/ht/urn.201405281857

Dor, A. (2012). Parents' Involvement in School: Attitudes of Teachers and School Counselors. Online Submission, US-China Education Review B, 11, 921-935.

Epstein, J. L. (1995). School/family/community partnerships. Phi delta kappan, 76(9), 701.

Germann, T. C., Gao, H., Gambhir, M., Plummer, A., Biggerstaff, M., Reed, C., \& Uzicanin, A. (2019). School dismissal as a pandemic influenza response: When, where and for how long? Epidemics, 28, 100348. https://doi.org/10.1016/j.epidem. 2019.100348

Gottfried, A. E., Fleming, J. S., \& Gottfried, A. W. (1998). Role of cognitively stimulating home environment in children's academic intrinsic motivation: A longitudinal study. Child development, 69(5), 1448-1460.

Mulenga, E. M., \& Marbán, J. M. (2020). Is COVID-19 the Gateway for Digital Learning in Mathematics Education?. Contemporary Educational Technology, 12(2), ep269. https://doi.org/10.30935/ cedtech/7949

Napoli, A. R., \& Purpura, D. J. (2018). The home literacy and numeracy environment in preschool: Cross-domain relations of parent-child practices and child outcomes. Journal of Experimental Child Psychology, 166, 581-603. https://doi.org/10.1016/j.jecp. 2017.10.002

Qi, W. (2017). Evaluating a Virtual Collaborative Environment for Interactive Distance Teaching and Learning: A Case Study. In Advances in Intelligent Information Hiding and Multimedia Signal Processing (pp. 11-18). Springer, Cham. https://doi.org/10.1007/ 978-3-319-50212-0_2

Sabar Ben-Yehosua, N. (1995). The qualitative research. Tel-Aviv: Modan. (in Hebrew)

Sintema, E. J. (2020). Effect of COVID-19 on the Performance of Grade 12 Students: Implications for STEM Education. Eurasia Journal of Mathematics, Science and Technology Education, 16(7), em1851. https://doi.org/10.29333/ejmste/7893 
Toquero, C. M. (2020). Challenges and Opportunities for Higher Education amid the COVID-19 Pandemic: The Philippine Context. Pedagogical Research, 5(4), em0063. https://doi.org/10.29333/pr/ 7947
Zippert, E. L., \& Rittle-Johnson, B. (2020). The home math environment: More than numeracy. Early Childhood Research Quarterly, 50, 4-15. https://doi.org/10.1016/j.ecresq.2018.07.009 